\title{
Innovation Technology of Lekor Dough Mixer Based Internet of Thing
}

\author{
Suzan Zefi ${ }^{1}$ Eka Susanti ${ }^{1, *}$ Sholihin Sholihin ${ }^{1}$ M. Zakuan Agung ${ }^{1}$ \\ R.A Halimahtussa'diyah ${ }^{1}$ Bong Siaw $\mathrm{Wee}^{2}$
}

\author{
${ }^{I}$ State Polytechnic of Sriwijaya \\ ${ }^{2}$ Polytechnic of Mukkah, Sarawak - Malaysia \\ *Corresponding author. Email : ekasusanti@polsri.ac.id
}

\begin{abstract}
The purpose of this tool is to help lekor entrepreneurs save time and make it easier for entrepreneurs to make lekor dough, because this makes kemplang faster by simply connecting an android smartphone to Bluetooth, the dough mixer can be controlled remotely but still have the maximum distance This tool is controlled using an Android smartphone and then connected to the Bluetooth driver on the device. Meanwhile, to control each component using Arduino. The maximum distance between the Bluetooth module on the device and the Android smartphone so that it can be connected is about 30 meters. The one that controls the system in this tool is the Arduino Uno. The program used in this tool is the MIT App Inventor. At the measurement of test point 2 on the Stepdown Vin module of 5.29 Volts, and Vout of 24.04 Volts. The DC to DC LM 2596 Stepdown Module is a module that has IC LM 2596 as its main component. There are several variants of this IC series which can be grouped into two groups, namely an adjustable version whose output voltage can be adjusted, and a fixed voltage output version whose output voltage can be adjusted, and a fixed output voltage version whose output voltage is fixed.

At the measurement of test point 3 on the Bluetooth $\mathrm{HC}$ module the maximum distance of Blutetooth is $30 \mathrm{~m}$. Bluetooth $\mathrm{HC}$ has 2 configuration modes, namely AT mode and Communication mode. AT mode functions to make configuration settings of the HC. Meanwhile, the Communication mode functions to communicate bluetooth with other devices.
\end{abstract}

Keywords: Android App, Arduino Uno, Emmbedded system, Electronic divice, MIT App Inventor,

\section{INTRODUCTION}

The industrial world has experienced rapid development so that many new technologies have emerged. Because the need to increase continuously requires a tool that can help work, minimize time and save human labor. Fish Kemplang is a typical Malaysia food made from tapioca, fish, water, salt and flavor. Making lekor is divided into several stages, namely: the fish milling process, the mixing of the ingredients, the steaming process, drying and frying. The quality of lekor dough depends on several factors, including good composition, accurate measurement of levels, optimal mixing and correct operating procedures.

In the fish lekor production process, the stirring stage is the activity that requires the most power so that many lekor producers or entrepreneurs do the stirring by trampling the dough with their feet so that it quickly becomes smooth. This method of stirring certainly affects hygiene lekor and when seen by consumers, will reduce appetite and buying interest. The manual method of stirring is usually consuming take between 50 and 90 minutes until the dough reaches a smooth finish The rapid development of the lekor industry in Malaysia has had a positive impact on the development of this traditional food and Palembang is one of the regional centers for the manufacture and processing of kemplang which has the potential to be developed even better, especially in planning and production processing which requires automatic dough mixer technology

The DC motor functions to move the dough mixer machine. DC motor or DC motor This motor produces a number of revolutions per minute or usually known as RPM (Revolutions per minute). If the value of Vin $3 \mathrm{~V}$ with a load of $0.5 \mathrm{~kg}$, the rpm is measured to be $362 \mathrm{rpm}$. Furthermore, if the value of Vin is 5 Volt with a load of $1 \mathrm{~kg}$, the velocity value is $306.3 \mathrm{Rpm}$. Then if Vin $10 \mathrm{~V}$ with a load of $1.5 \mathrm{~kg}$ the value is $268.4 \mathrm{Rpm}$. If the Vin $13 \mathrm{~V}$ value with a load of $2 \mathrm{~kg}$, the rpm value is 191.6 $\mathrm{Rpm}$. Furthermore, if the Vin value is $18 \mathrm{~V}$ with a load of $2.5 \mathrm{~kg}$, the result is the speed of $115.5 \mathrm{Rpm}$. And if the value of the voltage is $24 \mathrm{~V}$ with a maximum load of $3 \mathrm{~kg}$ 
the measured value of the speed is $78.6 \mathrm{Rpm}$. When a DC electric motor rotates with a small load, only a small amount of electric current or power is used and the Rpm value increases, but when a large load is given, the amount of current used will increase

At the measurement of test point 2 on the Stepdown Vin module of 5.29 Volts, and Vout of 24.04 Volts. The DC to DC LM 2596 Stepdown Module is a module that has IC LM 2596 as its main component.

At the measurement of test point 3 on the Bluetooth $\mathrm{HC}$ 05 module the maximum distance of Blutetooth is $30 \mathrm{~m}$. Bluetooth HC-05 has 2 configuration modes, namely AT mode and Communication mode. AT mode functions to make configuration settings of the HC. Meanwhile, the Communication mode functions to communicate bluetooth with other devices.

At the measurement of test point 2 on the Stepdown Vin module of 5.29 Volts, and Vout of 24.04 Volts. The DC to DC LM 2596 Stepdown Module is a module that has IC LM 2596 as its main component.

\section{DESIGN SYSTEM}

The block circuit diagram is one of the most important parts in the design of a tool because it is from this circuit diagram block that it can be seen how the circuit works, so that the circuit block diagram will produce a system that can be functioned or can work according to the design. The block diagram of the Arduino-Based Kemplang Mixer Tool Circuit Using Android is as follows:

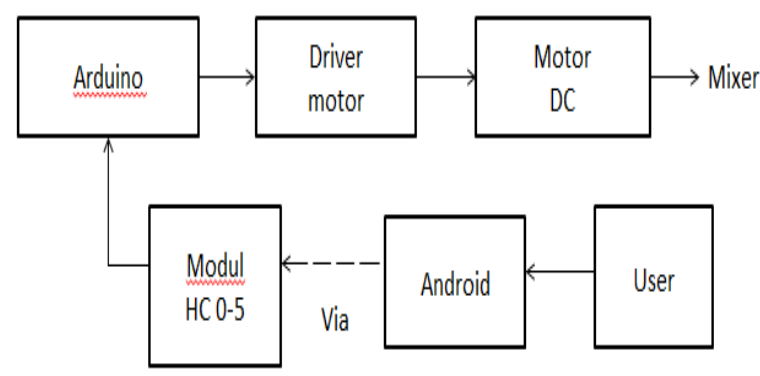

Bluetooth

Figure 1 block diagram of the tools design work system

Design is an important stage in the manufacture of an electronic device, but before designing the workpiece, a good plan must first be prepared to get satisfactory results. In the manufacture of this kemplang dough mixer is completed with the following work steps:

1. Manufacture of mechanical parts include:

a. Designingtools

b. Designing the shape of the doughnut

2. Filling programs on Arduino Uno and HC-05 Module

The testing and measurement process can be carried out after knowing the points to be tested and measured. From the measurement results in the HC-05 Bluetooth Module table with a distance of 1 - $30 \mathrm{~m}$ Bluetooth can still be connected, while with a distance of $31 \mathrm{~m}$
Bluetooth is no longer connected, so the maximum Bluetooth distance on this kemplang dough mixer is 30 $\mathrm{m}$. The measurement points can be seen in Figure 1 .

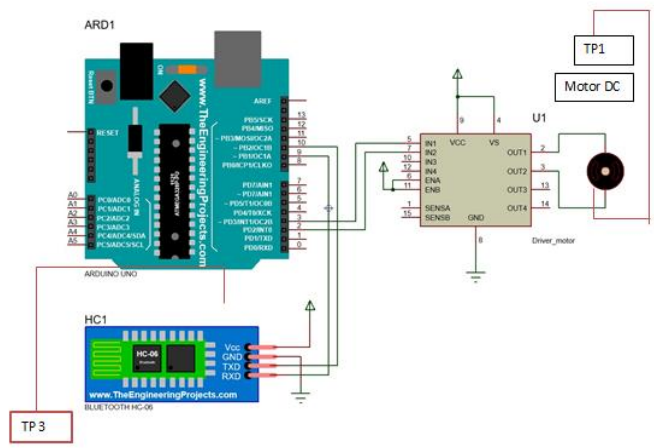

Figure 2 Design Component Layout

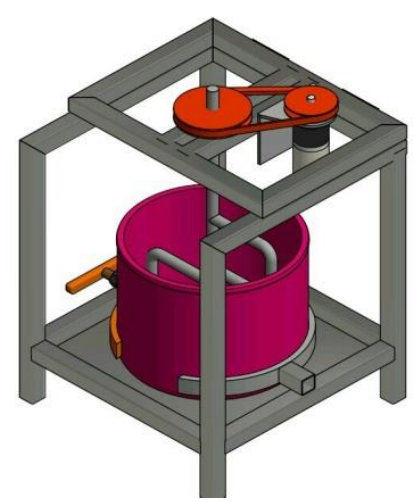

Figure 3 Result of the design of the lekor stirrer

\section{CURRETN RESULT}

From the results of the Bluetooth HC-05 measurement with a distance of 1-30 m, Bluetooth can still be connected. Meanwhile, with a distance of $35 \mathrm{~m}$, Bluetooth is no longer connected, so the maximum Bluetooth distance on this lekor dough mixer is $30 \mathrm{~m}$, you can be seen in the table 1 .

Table 1. Measurement Bluetooth Module HC-05

\begin{tabular}{|c|c|c|c|c|c|c|l|}
\hline No & Distance & Time & Source & Destiination & Protocol & Length & \multicolumn{1}{|l|}{ Info } \\
\hline 1 & $5 \mathrm{~m}$ & 0.000000 & $\begin{array}{c}\text { Host } \\
(192.168 .1 .33)\end{array}$ & controller & HCI_CMD & 6 & $\begin{array}{l}\text { Sent Exit } \\
\text { Sniff Mode }\end{array}$ \\
\hline 2 & $10 \mathrm{~m}$ & 0.003411 & $\begin{array}{c}\text { Localhost } \\
(192.168 .1 .33)\end{array}$ & remote & L2CAP & 18 & $\begin{array}{l}\text { Sent } \\
\text { Connection } \\
\text { Oriented } \\
\text { Channel }\end{array}$ \\
\hline 3 & $15 \mathrm{~m}$ & 0.003544 & $\begin{array}{c}\text { Controller } \\
(192.168 .1 .33)\end{array}$ & host & HCI_EVT & 7 & $\begin{array}{l}\text { Rcvd } \\
\text { command } \\
\text { status (Exit } \\
\text { Sniff } \\
\text { Mode) }\end{array}$ \\
\hline 4 & $20 \mathrm{~m}$ & 0.251055 & $\begin{array}{c}\text { Controller } \\
(192.168 .1 .33)\end{array}$ & host & HCI_EVT & 8 & $\begin{array}{l}\text { Rcvd } \\
\text { Number } \\
\text { Completed } \\
\text { Packets }\end{array}$ \\
\hline 5 & $25 \mathrm{~m}$ & 1.071459 & $\begin{array}{c}\text { Controller } \\
(192.168 .1 .33)\end{array}$ & host & HCI_EVT & 9 & $\begin{array}{l}\text { Rcvd } \\
\text { Mode } \\
\text { Changes }\end{array}$ \\
\hline 6 & $30 \mathrm{~m}$ & 1.077518 & $\begin{array}{c}\text { Remote } \\
(192.168 .1 .33)\end{array}$ & localhost & L2CAP & 14 & $\begin{array}{l}\text { Rcvd } \\
\text { Connection } \\
\text { oriented } \\
\text { Channel }\end{array}$ \\
\hline 7 & $35 \mathrm{~m}$ & 88.699040 & $\begin{array}{c}\text { Controller } \\
(192.168 .1 .33)\end{array}$ & host & HCI_EVT & 7 & $\begin{array}{l}\text { Rcvd } \\
\text { Disconnect } \\
\text { Complete }\end{array}$ \\
\hline
\end{tabular}




\section{CONCLUSION}

machine. DC motor or DC motor This motor produces a number of revolutions per minute or usually known as RPM (Revolutions per minute). If the value of Vin $3 \mathrm{~V}$ with a load of $0.5 \mathrm{~kg}$, the rpm is measured to be $362 \mathrm{rpm}$. Bluetooth HC-05 module the maximum distance of Blutetooth is $30 \mathrm{~m}$. Bluetooth HC-05 has 2 configuration modes, namely AT mode and Communication mode. AT mode functions to make configuration settings of the HC-05.

At a distance of $35 \mathrm{~m}$, the time when the packet is caught is 88.6990 and the source of the data packet is the controller with IP 192.168.1.33 which is the IP of the PC, the purpose of the packet data is the host, which is a place to store data or a server connected to the network, the protocol used is L2CAP ( Logical Link Control and Adaptation Protocol) is a protocol used in the Bluetooth standard that provides adaptation between the higher layers and the baseband layer of the Bluetooth stack, the data packet length is 7 bytes, and the captured information is Rcvd disconnect complete. thank finished.

\section{AUTHORS' CONTRIBUTIONS}

Contribution to the authors is making research data collectio and disign program applications.

\section{ACKNOWLEDGMENTS}

In writing this paper, the researcher has conducted several sample trials with reference to references as reference material, to improve this paper.

The researcher also thanks the previous authors, and the researcher also apologizes if there are different writing words.

Thank you.

\section{REFERENCES}

[1]. Arief.. 2014. Pengertian Fungsi dan Kegunaan Arduino. Diakses pada tanggal 24 Maret 2020. ariefeeiiggeennblog.wordpress.com/2014/02/07/pe ngertian-fungsi-dan-kegunaan-arduino/.
[2]. Adriansyah,Andi dan Hidyatama,Oka,2013, RANCANG BANGUN PROTOTIPE ELEVATOR MENGGUNAKAN MICROCONTROLLER ARDUINO ATMEGA 328P. Jurnal Teknologi Elektro . 4(3) : 102.

[3] Basith, Muhammad Abdul ,2017. PENERAPAN SENSOR ULTRASONIK HC-SRO4 PADA SISTEM PENGUKUR VOLUME PADA MOBIL TANGKI AIR BERSIH. Other thesis, POLITEKNIK NEGERI SRIWIJAYA

[4]. Budiharto, Widodo. 2004. Interfacing Komputer dan Mikrokontroler . Jakarta: PT Elex Media Komputindo.Glaser, Horst Albert dan Rossbach,,Sabine. 2011."The Artificial Human", Frankfurt

[5]. Eka susanti, Rosita febriani, Sholihin, Eka susanti, Emilia hesti, 2018, The design of hand gesture robot software based on wireless technology, IEEE conferences ICOIACT 2018, Indonesia, p.p 401 406.

[6]. Harmalia, Dita. 2015,"PENGATURAN OTOMATIS GERAK KAMERA PADA ROBOT PENDETEKSI LOGAM DI AIR TAWAR BERBASIS MIKROKONTROLER ATMEGA 16”. Other thesis, Politeknik Negeri Sriwijaya.

[7] Pitowarno, Endra. 2006. Robotika Desain, Kontrol, dan Kecerdasan Buatan. Yogyakarta: Andi

[8] Sholihin, Eka Susanti, "Humanoid Robot Control System Balance Dance Indonesia and Reader Filters Using Complementary Angle Value", E3S Web of Conferences 31, 2018

[9] Thangavel, D. 2014. Performance Evaluation of $M Q T T$ and CoAP via a Common Middleware, Singapore. 